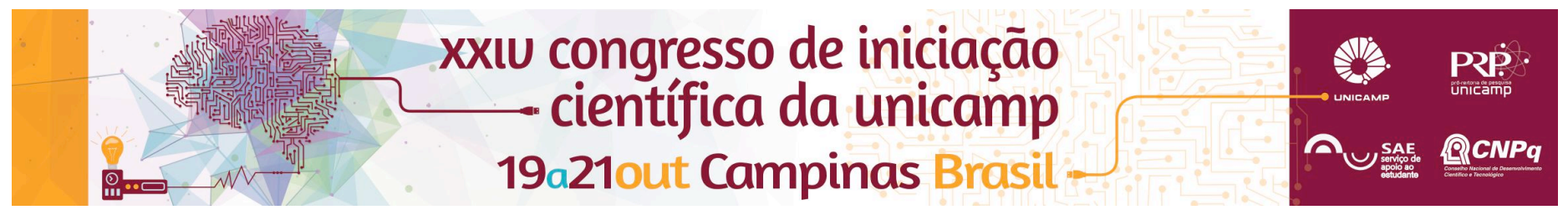

\title{
Aspectos da política habitacional e as Zonas Especiais de Interesse Social I (ZEIS I) na área central de Campinas - SP
}

\author{
Pedro Langella Testolino*, Sidney Piochi Bernadini
}

\begin{abstract}
Resumo
Um dos principais instrumentos criados no âmbito da reforma Urbana no Brasil a partir da promulgação do Estatuto da Cidade (Lei Federal 10.257/01), são as Zonas Especiais de Interesse Social (ZEIS), estabelecidas a fim de facilitar às classes sociais menos favorecidas e excluídas do mercado de habitação, o acesso à moradia e à cidade. Esta pesquisa procurou investigar a atuação do poder público na política habitacional do município de Campinas, no que tange à demarcação e implementação das ZEIS I (chamadas de ZEIS de indução) em sua área central. Através de levantamento e análise de planos, legislação e bibliografia pertinentes ao tema e de entrevistas com profissionais da esfera pública, foi possível compreender o percurso utilizado pela Prefeitura de Campinas para evitar a implementação destas Zonas na área central da cidade e, ao mesmo tempo induzir a produção habitacional de interesse social, de forma segregada, em algumas regiões mais periféricas do município.
\end{abstract}

\section{Palavras-chave:}

Zonas Especiais de Interesse Social, área central, Campinas.

\section{Introdução}

O objetivo principal da pesquisa foi verificar de que forma a política habitacional do município de Campinas e as diretrizes traçadas pelo Plano Diretor, de 2006, e pelo Plano Municipal de Habitação, de 2011, trataram a questão das ZEIS na área central (Macrozona 4). O Plano Diretor de Campinas, Lei Complementar 15/06, incluiu, no seu rol de instrumentos urbanísticos, as ZEIS (Zonas Especiais de Interesse Social), classificadas em duas categorias: as ZEIS 1, voltadas para a construção de empreendimentos habitacionais de interesse social e as ZEIS 2 - voltadas à regularização e urbanização de áreas já ocupadas. Considerando que Campinas possui um déficit habitacional que chega a 40 mil unidades habitacionais e que o Plano Municipal de Habitação, concluído em 2011, reforçou a importância das ZEIS como reserva fundiária para a implantação de moradia social, procuramos compreender quais froam os impasses e tratativas que vêm sendo realizados para efetivar tal instrumento na área central de Campinas, que possui um conjunto amplo de imóveis vagos e subutilizados, inclusive de domínio público. Por fim, procurou-se compreender e refletir o porquê do Poder Público municipal desenvolver uma política habitacional segregacionista, deixando de abranger uma região dotada de infraestrutura urbana, como é o caso da área central de Campinas.

\section{Resultados e Discussão}

Analisando percurso legislativo relacionado a Empreendimentos de Habitação de Interesse Social (EHIS) do município de Campinas, bem como da própria produção em si, foi possível identificar que a Prefeitura Municipal teve papel determinante na manutenção do padrão periférico de urbanização, implantando bairros populares afastados do centro ${ }^{1}$. Esta intenção fica clara com a promulgação da Lei de EHIS, já em 1997 (Lei 9.342/97) e modificada em 2000 (Lei 10.410/00), reduzindo exigências documentais, da contrapartida social exigida e excluindo a limitação de faixa de renda do público alvo, abrindo caminho para a produção habitacional não necessariamente social a partir das flexibilizações proporcionadas aos empreendedores. Em
2006, o Plano Diretor demarcou alguns perímetros de ZEIS, remetendo, entretanto, a delimitação de novos futuros no Plano Municipal de Habitação e nos chamados Planos Locais de Gestão (PLG), que deveriam ser aprovados por lei. O Plano Municipal de Habitação (2011) chegou a levantar e propor terrenos de ZEIS 1 na área central, os quais não foram levados a diante pela municipalidade. Esta, por sua vez, não concluiu o Plano Local referente à Macrazona 4 (área central), demonstrando desinteresses pelas propostas ali contidas. Não coincidentemente, o Plano Local relativo à Macrozona 5, integrante do vetor sudoeste de expansão urbana da cidade (que segrega a população mais pobre), foi concluído e com delimitação das ZEIS I no ano de 2012. Além disso, em 2014, foi promulgada a Lei Complementar 70 que, com o discurso do incentivo à produção de EHIS, deslegitimou plenamente o instrumento das ZEIS ao permitir a produção de HIS em qualquer área urbana das macrozonas.

\section{Conclusões}

Evidenciou-se que os impasses referentes às ZEIS I, na área central do município de Campinas-SP, são fruto das estratégias segregacionistas do Poder Público municipal. Embora levantamentos como os realizados pela DEMACAMP $^{2}$ em 2013 e Carty $^{3}$ em 2014 tenham indicado a presença de grande número de imóveis vagos na região, o Poder Público vem criando mecanismo que flexibilizam a produção de HIS, ao invés de regulá-la, a fim de manter a população de baixa renda na região periférica e manter os imóveis vagos da região central como reserva de mercado para empreendimentos futuros, contribuindo para a especulação imobiliária.

\section{Agradecimentos}

À Fundação de Amparo a Pesquisa do Estado de São Paulo - FAPESP pelo fomento a essa pesquisa.

\footnotetext{
${ }^{1}$ CARVALHO, E. Crise urbana e habitação popular em Campinas, 1870-1956. Campinas, 1991.

${ }^{2}$ DEMACAMP. Levantamento de cortiços e imóveis ociosos e subutilizados no centro. Campinas, 2013

${ }^{3}$ CARTY, Carolina G. Vacância no centro de Campinas e o planejamento brasileiro, 1990-2014. Campinas, 2014.
} 